\title{
An Assessment of the Causes of the Madhesh Movement 2015
}

$\sim$ Sedunath Dhakal ${ }^{1}$

\begin{abstract}
Conflict in a place is not caused by only a single factor. Many socio-economic, political and cultural factors are responsible to create a violent conflict. Nepal faced sociopolitical and regional conflict during the past decades, particularly after a decadelong Maoist insurgency had come to an end with peaceful resolution. The people's movement 2062-63 overthrew the century-long monarchy system of governance, but there occurred different ethnic and regional movements for the identity and recognition. The Madhesh Movement of 2007 and 2015 were very remarkable for the socio-political changes in Nepal. There are many reasons behind Madhesh Movement 2015. This paper has analyzed the four major factors that caused the Madhesh Movement 2015, which are: (i) Poverty, Discrimination and Exploitation (ii) Exclusionary Nature of the State (iii) Influence of Ethnic Movements of Nepal in the Madhesh Movement 2015, and (iv)The Madhesh Movement for Identity. Although the movement occurred throughout Madhesh, four major conflict zones viz. Biratnagar, Janakpur, Birgunj, and Tikapur were taken as the research site. Owing to the same fact, this research paper is based on the response of the people from the conflict zones, experts' opinions about the conflict, and the selected newspaper opinion articles during the major conflict period.
\end{abstract}

Keywords: Madhesh, Identity, Ethnicity, 2015.

\section{Introduction}

Conflict is a very complex social phenomenon, so it can neither be understood nor be analyzed from a single lance. It can only be "understood and explained from multidisciplinary boundaries"(Demmers 2). No single clear-cut reason can be identified to explain why Nepal has been affected from prolonged conflict, but the understanding of the causes and nature of conflict is needed to make a proper analysis how to resolve it in an appropriate way. Considering the "heterogeneity of conflict" (Demmers 2), we should look and understand the various dimensions of the conflict in Nepal. Some believe that it has been ethnicity labelled and influenced from international identity movements. Some think that it's been completely a political issue. The political elites instigate the ethnic and regional conflict for the sake of power as the bargaining political agenda.

1 Dhakal is an Assistant Professor at Koteshwor Multiple Campus (KMC). He is the Head of English Department (HoD) at KMC and teaches poetry, prose, drama to the B.A.-Level Students, and Research Methodology on Managerial Communication to the Master-level students at KMC. 
There are many direct and indirect factors associated to the Madhesh movements. Like in other regions of Nepal, the Madhesh also is suffering from social injustices like corruption, nepotism, caste and class discrimination and other evil practices. There is lack of access to justice to the Madhesis ${ }^{2}$ people. It is because the norms and values, rules and regulations, constitutional practices, social systems are in favour of the socalled upper caste Pahadi community people.

Another indicator of the conflict and violent moment in this region is the poor economic condition of Madhesis people. Many people in Madhesh are living under poverty in spite of having fertile and easy geographical structure, and easy access to the huge marketplaces. It is because of the lack of proper planning and policies of the state to address the problems of the Madhesis. Many Madhesis youths are uneducated and those who are educated are unemployed. They have been easily mobilized in the movements as the youths are naturally more ambitious and prone to violent movements if they are guided by certain greed and grievances. Another important factor of Madhesh conflict was unstable political condition and the lack of political representatives in the nation from Madhesh. If both the state and its administration become weaker there is greater chance to occur conflict. There is also an influence of international identity movements which created the awareness, and mass mobilization of the people for their rights and justice. After the socio-political changes that took place in Nepal in 2007, such ethnic and cultural movements began spontaneously.

By taking the supports from the international experiences of the violent conflict and the analysis, this research specifically focuses on the causes or the factors affecting the Madhesh movement 2015. Although there are many reasons behind such uprising as mentioned above, this paper has explored on these four main reasons of the conflict in the study area:

a) Poverty, discrimination and exploitation

b) Exclusionary nature of the state

c) Influence of ethnic movements of Nepal in the Madhesh movement 2015

d) The Madhesh movement for identity

\section{Poverty, Discrimination and Exploitation}

The Madhesh consists of heterogeneous identity groups of people based on ethnicities, castes, language, religions and culture, so it's like "a melting pot"( NEMAF Report -2013 39). It has many pull factors for internal migration from the hilly region of Nepal and external migration from India. Some of the pulling factors are transportation, communication, easy market access for the business, and its fertile land for cultivation. In spite of having easier geographical structure, better infrastructure and more cultivable

2 People living in Madhesh. But the government of Nepal hasn't listed some people from Pahadi ethnic origin who have been living for long time in Madhesh in the list of 'Madhesis'. 
land, there are many socio-economic problems prevalent in the Madhesh. It has been crippled with various problems like poverty, illiteracy, class and caste discrimination, corruption, border crisis and internal conflicts within. Some of the past years in the Madhesh have been experienced "by growing statelessness, radicalization, multiple conflicts, a weak and insensitive administration and above all bad governance. All these things have led to an insecure, fearful and corrupt environment in the Madhesh" (NEMAF Report 2013 1).

Conflict is not only caused by a single factor; it is very complex in its nature. It depends on the socio-economic and political situation, and geographical location of the place. Conflict in Madhesh can only be understood after understanding different factors directly and indirectly associated with it. "Underlying causes of Madhesh conflict along four different axes according to Michael E. Brown : structural, political, economic/social, and cultural/perceptual " (quoted in Sijapati 148). These causes are also interlinked and associated to other socio-political and identity movements because of the similar nature of the state controlled by upper-caste rulers from Pahadi ${ }^{3}$ community for long time in its history.

Class and caste barriers in different socio-political opportunities have suppressed more to the disadvantaged communities in Madhesh. It has also contributed to make the lower caste and the poor Madhesis feel double exploited as opined by C.K. Lal, "caste distinction in the political economy of Tarai-Madhesh is another reason behind lack of cohesion in the community" (Lal 6).

The nature of Nepali society is based on either caste and ethnicity or the geographical region. All socio-cultural and political power remained only in the hand of so-called upper caste Pahadi people and Madhedh was always excluded from the state. The marginalized groups naturally try to find out the favourable time and situation to revolt against the domination. After the end of Monarchy and unilateral governance system, different identity movements began throughout the country, and "Madhes Andolan is a manifestation of historical marginalization and alienation experienced by Madhesis at the hands of a succession of ruling elites of Nepal" (Sijapati 149).

The consciousness of the Madhesis people about their rights has been dramatically increased after the historic Madhesh movement of 2007, and 2015 in Nepal. "The feeling of relative deprivation and the resultant absence of recognition of Madhesis as Nepali citizens and their exclusion from national life, I argue, was one of the main factors that precipitated the Madhes Andolan" (Sijapati 149). The local, national and international activists from Madhesis origin began supporting and encouraging the people to raise the voice against the domination of Pahadi rulers. The new constitution ${ }^{4}$,

3 People living in the hilly region of Nepal. They include Khas/Aryas (Brahmin Chhetries), Janajatis (ethnic people in the hill), and Hill dalits.

4 The Constitution of Federal Democratic Republic of Nepal promulgated on 20 September, 2015 
as they argued could not address the feelings of Madhesis people. "It was supposed to enshrine equality for women and historically marginalized groups, but many people in this country of 28 million insist that it does none of these things" (Upadhyaya 6).

According to Krishna Hachhethu, the causes of Madhesh movements were:

"socio-cultural discrimination, economic exploitation, administrative discrimination, and political exclusion" (Hachhethu 33-34 - my translation). Hachhethu also explains that the people involved in the Madhesh movement were raising their voices and fighting for the "identity, proportionate election system, inclusive state, and federalism with identity" (Hachhethu 36 - 37 - my translation). The discrimination and exploitation for long in Madhesh made the people more emotional and prone to violence which appeared in different forms in different places.

According to Tula Narayan Sah, two major problems in the Madhesh are: lack of development, and corruption. He argues that "there is 60-90\% corruption in local level development in Madhesh" (Sah 6) Because of the lack of political representatives in the local level in Madhesh the corruption has been institutionalized. No leader seems to be responsible and worried about the welfare of the people since s (he) doesn't need to face the election. The allocated budget is spent and officially managed by some corrupt leaders and political and administrative agents without the consent and mandate of the people. Manil (name changed) Parajuli, an inhabitant of Chandrapur - 10, Rautahat, opines that the Madhesis people are suffering from internal conflicts because of class and caste discrimination. He says, "There is more exploitation and discrimination within Madhesh rather than from Pahadi people and the state. They are suffering from their own problems". ${ }^{5}$ He represents the voice of permanent hill dwellers in Madhesh but is afraid of the disharmonious situation after the conflict.

But the opinion of Mr. Prajapati (full name not mentioned) from Mahottari is different. To the question asked, 'What is the real problem of Madhesh that made the people involved in such violent conflict?'. He replied that it is because of the state's "discriminatory policies. The Madhesis people were always excluded by the state; they were not recognized at all. There remained prolonged oppression, suppression, discrimination, and marginalization as the root cause of Madhesh conflict" ${ }^{6}$ If the voice of the marginalized community is suppressed, no doubt, it burst in a way or other; nobody can control it forever because the political 'Pandora box' has already been opened.

While talking to some permanent residents of eastern Madhesh districts: Morang, Sunsari and Saptari with mixed community people it was found that the class discrimination is one of the major problems of in this region. The landowners and

$5 \quad$ Interview taken on December 30, 2016.

6 Interview taken on December 1, 2016. 
other rich people behave the lower class, poor as their slaves and they have to tolerate. Caste hierarchy is also strictly in their day to day practices. The lower caste and poor people have been doubly marginalized and exploited, and they were easily mobilized in the movement with the expectation that they would get more freedom.

\section{Exclusionary Nature of the State}

The Madhesh and the people living there have been excluded from the access of the national resources and the opportunities for two and half centuries since Nepal was unified by Prithvi Narayan Shah ${ }^{7}$. The exclusionary legacy of the rulers continued by Rana, Panchayat, and other democratic leaders too. Socio-political, cultural and legal system of the state of our country is in favour of the upper caste Pahadi people. According to Krishna Kumar Sah;

The traditional Nepali social structure is quite exclusionary. People are excluded in the social space on the basis of language, caste, religion, region and culture, which leads to disadvantages to certain communities. Social exclusion, no doubt, is the historical product of a discriminatory state system in Nepal. In the long history of 248 years, the state could never be a people's state. Rather, a few groups, namely the Shahs, Ranas, and Parbatiyas, ruled the country according to their wishes and interests throughout the period. The regimes were totalitarian, autocratic, despotic and tyrannical. (Sah 4)

Although the Shah dynasty was over, similar trend continued to other Pahadi rulers who tried to define the nation and nationality in their own favour, excluding the voices and representation of other historically disadvantaged communities: Madhesis, Aadhibashis, and Dalits. The trends of "transfer of power has changed from bloodline and faith to caste-line and politicking, but all other elements of prejudices against Madhesis in the state structure remain the same" (Lal 6). Sah further adds that the "exclusion in hundreds of its forms, such as discrimination, injustice, oppression and exploitation, was institutionalized and sustained legally to fulfil the rulers' interests and sustain their rule" (Sah 4). Exclusion became institutionalized, so the marginalized and disadvantaged communities were deprived of getting the equal opportunities in none of the socio-economic, political, administrative, educational, and security system of the state. The nature of the state remained all the time unilateral, "being ruled by one caste group (Brahmin/Chhetri/Thakuri), one religion (Hinduism), one language (Nepali/Khas), one origin (Parbatiya/hill dwellers) and one sex (male), and all the other social groups were excluded" (Sah 4).

But there is discrimination within Madhesh itself. It is believed that the class and caste discrimination and inequality in Madhesh has made the society disharmonious. The poor and Dalits in Madhesh were doubly exploited. According to Promod Mishra, "the

$7 \quad$ The King of Gorkha (1723-75) who became the king of united Nepal after he conquered many small states in 1769 
result of Madhesis social structure and the historical discrimination of the Nepali state against the Madhesis community is a double strike against the Madhesis Dalit" (Mishra $6)$.

The Madhesis were excluded more than even other ethnic and Dalits by the state. According to Arjun Guranatne,

Madhesis also share with Janajatis and Dalits their relative marginalisation in government and military service, especially at senior levels. Madhesis are perhaps more marginal than most; unlike the Janajatis, they tend not to be recruited into the military, and relatively few have been taken into the bureaucracy. (Gunaratne xix)

Krishna Hachhethu made it clear that there are many reasons why the Madhesis people had been suppressed and remained silence throughout many centuries. He opines that, "Some parts of the lands in Tarai were ruled by both Nepali and Indian rulers before the Sugauli Treaty between East India Company and Nepal in 1816 even after many years" (Hachhethu 31-my translation). Nepal had got four district of Western Terai: Banke, Bardiya, Kailali and Kanchanpur (which was called 'the new land') 40 years after the Sugauli Treaty. So the people of that region could not feel recognized like the people in other region for centuries. From 1846 to 1950, the Rana Regime of Nepal did not allow any Nepali to raise the voice against the state, and from 1960 to 1990 the Panchayat Regime of Nepal restricted different cultural identity in Nepal. Hachhethu further mentioned;

There was a slogan in Panchayat Regime: 'Eautai Bhasa Eautai Bhesh Eautai Jati Eautai Desh' (One language, one dress, one caste, and one country). There were four images of being a Nepali: to know Nepali language, to be a brave Nepali (Gorkhali/Parbate), to respect monarchy, and to be Hindu. Madhesis people had no relation with the first two, after 2007 AD latter two images also were denied constitutionally from Nepal. So, only after 2007 AD the Madhesis nationalism emerged, and it was established as a political force. (Hachhethu 31-my translation).

Arjun Gunaratne also has similar arguments. He writes;

Nepal's traditional elite, restored to the center of power after King Mahendra's coup in 1960, sought that identity in the symbols that were most meaningful to them. Thus, in the eyes of the state, to be a Nepali required the adoption of the symbols of the dominant Bahun-Chherti groups, in dress, ritual and language. (Gunaratna xix)

The issue of identity was always suppressed before 2007 in Nepal. Hachhethu argues that, "All three great political movements of Nepal in 1950, 1990 and 2006 were to end certain autocratic regimes namely Rana, Panchayat, and Monarchy" (32). But it 
was only the Madhesh movement of 2007 which could establish the federal democratic system with identity in Nepal. So the issue of identity became important in the Madhesh.

Before 2007, the politics in Madhesh was led by so-called high caste and were from rich family backgrounds like landowners or the industrialists, but the Maoist movement and the Madhesh movement of 2007 gave birth to the leaders from lower caste and class. As a result, the Madhesh based parties, could elect more representatives from Madhesh in the elections after 2007. The present leadership representing different caste and communities from the Madhesh could easily mobilize the people in the movements after 2007 by making them aware that they had been historically suppressed and excluded from the Pahadis.

As Hachhethu argues "the Madhesis people were not concerned about what's going on in Nepal. Rather they knew something about Bihar or U. P. of India because of their accessibility" (Hachhethu 31-33 -my translation). But, after they had been guaranteed to get the rights of inclusive participation in all positions of the state powers in the interim constitution, they became careful whether such guarantees get fulfilled or not. While drafting the constitution in 2015, the representatives from the Madhesh based parties felt that it would not fulfil the demands of the Madhesis people as they were guaranteed in previous agreements and interim constitution, as a result, they left the CA and began the second Madhesh movement which continued for many months after the constitution was promulgated.

Talking about how the state itself was biased against Madhesh, Sanjay Singh reasoned; "had there not been such discrimination against us, there wouldn't have had Madhesh Bidroha. It has been proved that the state itself is doing discrimination, and it is not able to maintain the mutuality" (quoted in Sah 45-my translation). Because of the extreme form of discrimination and exclusion, there emerged hatred feelings and grievances in the Madhesis youths which ultimately led to politicization of ethnic violence.

Saurav Sharma, while evaluating the Madhesh movement of 2015 argues that the exploitation of the state is the root cause of the conflict. He opines that there is discrimination and exploitation within Madhesh itself: class and caste discrimination prevail everywhere. He adds;

It's not only because of the exploitation of the state (ruled by the Pahadi) there is problems in the Madhesh. To make a separate and independent Madhesh is not an ultimate and all in all solution for the development and prosperity of the Madhesh. We should explore the real problems of the Madhesh. (Sharma 7 - my translation)

But it's not only the exclusion and exploitation of the state because of which Madhesh has been suffering, the exclusion and exploitation exists within there. Ram P. Sah 
reasoned; "what happens if Pahadi ruler is kicked out of the power, there comes another exploiter from Madhesh. Only Topi is removed in the head of representative, but the trends of exploitation is still the same" (quoted in Shah 50 -my translation). He tried to make it clear that the federal system has to be implemented to end such exploitation."But federalism without identity leads to division of nation. If anybody thinks such federal division without identity, it's only the division mentality" (quoted in Sah 50 - my translation).

However, the Pahadi Brahmin-Chhetry people have different argument regarding federalism. They think that it would lead to division of a nation, as Rajendra Adhikari opines; "caste-based federalism divides the nation. There will be civil war if it happens. So we are against it" (quoted in Sah 53 - my translation).

Parshu Ram Bhagat Tharu argues that; "if there is problem in Pahad, it's not because of the Madhesis who reached and created the problems, but it's the Pahadi people who have created such problems in Madhesh. For example in Biratnagar the Rickshaw pullers always get insulted and scolded by Pahadi" (quoted in Sah 53.- my translation). The Madhesis labour workers could not feel the dignity of their labour in their own land. The bitter reality is that, instead of getting thanks for their great contribution, they get scolded.

There are many other factors contributing to each other to create more pain to Madhesis that compelled them to involve in the conflict with the hope that they would get relief. Madhesis people could not feel that this nation is their own. They have been judged only from Pahadi looking glass. According to Basudev Niraula from Sarlahi; "there is problem in getting the citizenship. There is very rare number of Madhesis people in civil servant and security force of Nepal. It is because of the exclusionary nature of the nation itself" (quoted in Sah 5, - my translation). The Pahadi administrator would judge the Madhesis as Niraula said levelling as 'Bihari'8 or Indian without trying to understand the reality. He also argues that; "revenue collection is more from Madhesh than from Pahad, but the less budget is spent in Madhesh, and there is less participation of the innocent local Madhesis people in the projects. Poor Madhesis are always poorer" (quoted in Sah 58 - my translation). Although the income of the nation is more from Madhesh, this region has been always excluded as Arjun Gunaratne writes;

Although the Tarai has been central to the economic viability of the Nepali state since its inception, the people of that region have been politically marginalized and treated with suspicion by the hill-based elites who ruled the country. (27-28)

Balaram Timilsina argued; "Madhesis people have been tolerating the misbehaviours

$8 \quad$ People originally from Bihar of India who are temporarily living in Nepal, particularly in Madhesh for different purposes. 
and exploitation from the state, always governed by the Pahadi rulers for the centuries. Thus the Madhesis people have feeling of hatred and rage against the state" (Timilsina 7-my translation).

Some national and international groups are trying to get the benefits by widening the gaps between Madhesh and Pahad, and weakening the social harmony. According to Dipendra Jha, a lawyer at the Supreme Court; "there are the forces that are trying to polarise the two communities, Pahadis and Madhesis, and trying to portray the Madhesis as Indians" (Jha 7). Such attempts may ultimately weaken the social harmony and democratic political system. Such situation has been occurred because there are many ethnic, socio-economic, religious and political problems although Nepal is geographically a small nation. The Madhesh has a "long history of marginalization, a fact accepted by almost all the leaders of the country. So, it's a mystery why they don't try harder to solve the problem" (Chaudhari 6). The problem is known, but there is lack of political determination of both the Pahadi and the Madhesis leaders to solve the problems of Madhesh.

\section{Influence of Ethnic Movements of Nepal in the Madhesh Movement 2015}

Ethnicity is a primordial identity of the people that makes them different than others. It is "related to a sense of belonging based on the belief in shared culture and common ancestry. However, where primordialists see the ethnic group as a natural community, the constructivist approach claims it is socially constructed" (Demmers 24). Human beings are social and cultural beings, so they feel proud of certain identity that belongs to their culture and ethnicity. The concept of ethnicity is naturally ingrained in the blood, and can't be changed, as Jolle Demmers adds, "ethnicity is a natural, inevitable fact of life. Ethnicity is seen as a communal bond given by nature, as something that is in your blood, and therefore unchangeable" (24).

Traditional concept of nationality in Nepal was just to follow the ethnic norms of the Pahadi Brahmin- Chhetry: to speak correct Nepali, to wear Daura-Suruwal and Dhaka Topi, and to follow other cultural values. It was neither political nor geographical, because of which the Madhesis and Ethnic (Janajati) communities could not get recognized. Because of the discrimination and oppression to the lower caste, there appeared the polarization in society on the basis of ethnicity and the political leaders representing certain ethnic communities tried to politicize the ethnic identity movements. The violence could have "powerful effects on the politicization of ethnicity" (Mathema 75). Ethnic activists who have been involved in ethnic movements after 2007 in Nepal went on making harsh comments against the upper caste Pahadi people and the state. The political elites from the Madhesh "politicized ethnicity as a means by which they can acquire and maintain political power in the country" (Latigo 89). The trend further moved to indirectly support to the Madhesh movement. It was because, as opined 
by Hom Bahadur Galami from Sarlahi, "the problem of Madhesis, Adibasi/Janajati, Muslim, and Dalit is similar. It is the movement against the state which excluded all of them in the same way" (quoted in Sah 75).

Many contemporary conflicts are guided by the emotions of the people. They "revolve around narratives of origin and blood, where the territorial claims of forebears on ancient soil are relived and used to legitimize contemporary and future violence."This is my land. You do not belong here. We were here first" (Demmers 25). Madhesis people thought that Pahadis were exploiting them although they had the right to claim Madhesh was their land, their own. The Madhesis nowadays don't hesitate to claim 'Ham bideshi bhagauda nai, dharti putra chhi' (We are not the foreigners, we are the native sons of this land). But there was a debate among different ethnic people within the Madhesh itself about who were the aboriginal people of Madhesh. The Tharus claimed that they were only the people living in this plain land before people migrated either from the south (Now in UP and Bihar) or from the north (the hilly region of Nepal). But other communities denied this claim and argued that there were different ethnic people living in this land who could face extreme heat and malarious ecological environment on the river banks near the dense forest. Later in the favourable situation other people migrated to Madhesh.

Stereotypes, and hatred and enmity are some major factors that perpetuated the conflict in the Madhesh. There has been a strong emotional bond of all ethnic communities throughout the nation after the April movement of 2007 against the autocratic rule of the King Gyanendra. Ethnic and cultural symbols and stereotypical images have been used to trigger out the conflict by creating the enmity during the movement. There appeared feeling of hatred from one ethnic community to the other. Observing the Madhesh movement 2015, Keshav Pradhan, writes in the Times of India, that Nepal has been ethnically divided which is not a good symptom. He argues;

Nepal, which for almost nine years ran without a permanent constitution after it abolished monarchy, stands as bitterly divided as Afghanistan on ethnic lines. Ethnic groups fighting for more autonomy are busy expanding their areas of influence. The most vociferous of them are Madhesis (Maithili, Bhojpuri, Avadhi, Hindi and Urdu-speaking people) and Tharus, who live in the Terai bordering Bihar and U. P. (Pradhan 5).

But the politicians from the Madhesh based parties deny his claim. They think that this movement is not an ethnic one, but a political movement. Hridesh Tripathee, assistant president of Terai Madhesh Democratic Party (TMDP) called it a "Jana Bidroha" (quoted in Premarshi and Sah 12). It was a socio-political movement because the demands it raised were not the ethnic, but for the political rights. 
The Madhesh movement 2015 has been influenced directly and indirectly by the different movements for the recognition of ethnic and cultural identities in Nepal after 2006. Michael E. Brawn thinks that there are many reasons behind such regional conflicts like the "socio-economic, cultural, political and administrative structure of the state" (quoted in Sijapati 148). These factors were also seen as the main source of Madhesis' grievances. But this grievance is not only limited to the Madhesh. Nepali state's long-time domination by so-called upper caste hilly people to the marginalized lower caste and the Madhesis people continued even after the restoration of democracy in 1990. The political parties and the frequently-changing government they formed and dissolved could not address the problems and demands of the marginalized lower caste people. These marginalized people were mostly mobilized in such movements because of the expectation that the newly formed ethnic and regional political parties involved in the political movements after 2007 would guarantee their rights and recognition.

Ethnicity based and regional parties were formed after the democratic exercises began in Nepal after 1990. Main agendas of some of the parties were the fulfilments of the demands of certain ethnic or regional community people. "Among them were: Nepal Rastriya Jana Mukti Morcha (NRJMM), Nepal Sdbhavana Party (NSP), Nepal Rastriya Jana Mukti Party (NRJMP), Nepal Janajati Mahasangh (NJM)"(Bhattachan 35). There increased the role of national and international non-governmental organizations to support these parties. After 1990, identity became a serious issue in the socio-political discourse of Nepal. Ethnic people throughout the country and the people living in Madhesh, as some western scholars opine are fighting for "equality, democracy, human rights, and secularism. Some Western and Nepali ethnic scholars have portrayed BahunChhetris as the exploiters, oppressors, and internal colonizers" (Bhattachan 38). These scholars also opine that the so-called upper caste people who are in power have created a myth, a sort of discourse of social and ethnic harmony that became the normalcy in the society. If the dominated caste raises the voice for the justice and equality, it would become a matter of social disharmony in the eyes of power holders who are mostly Chhetry-Brahmins.

But the ethnic politics of Nepal during the late 90 s changed its course from socio cultural advocacy towards the establishment of political parties. The CPN (Maoist) began its armed movement in 1996, and it openly incorporated ethnic agendas to fulfil its political strategies. As a result, it could mobilize all ethnic groups and lower class/caste people to go against the state which always had suppressed them for ages. The Maoist rebels raised issues of marginalized communities, establishment of ethnic autonomy and the federalism on the basis of ethnicity. The discriminated and disadvantaged ethnic groups including Dalit, Madhesis and Muslim share the "common goal of ending the dominance of the state" (Hangen and Lawoti 18). All their demands are in one level 
same; that is, the ethnic and cultural recognition and their equal representation in the state affairs. And so, it is because of the failure of the constitution of Nepal 1990, and the common grievances of all marginalized communities against the state, Nepal faced the rise in ethnic identity politics and the ethnic conflict together with other political conflicts after mid-nineties. Nepal Aadibashi Janajati Mahasang (NAJM) with the inclusion of other many member organizations became the leading organization to raise the issues of nationalities against the state. From 2002, the Mahasang has been involved into political activities and "in 2007 it signed 20-point agreement with the interim government which promised the proportional representation on the basis of ethnicity in the Constitutional Assembly, and at all levels of state, among other things"(Hangen and Lawoti 20).

Hridesh Tripathee blames the party leaders from the Pahadi communities that they are against identity based federalism. He argues, "they want to continue the power of the Pahadi upper caste people if possible in all federal states. So they don't want to separate Madhesh from Pahad"'. Their majority became decisive to make the new Constitution of 2015. Many people have been killed and many were injured in the Madhesh movement protesting against the constitution. Because of the Madhesh movement and India-Nepal border crisis, the situation of unofficial embargo has been created for many months from India to Nepal. It affected the life of Nepali people severely.

\section{The Madhesh Movement for Identity}

People have certain characteristics by which they are recognized or known to each other. Identity is a sentimental feelings of a person in which one finds the "answer to the question "who am I'?" (Demmers 20). It is shaped by more emotional thinking than the rational logic. So, it is more difficult to define in words, but "experienced as sameness, as essentially sharing a 'common mental construction'. It is the most individual sensation of a person's unique sense of self; that is, being utterly unlike anyone or anything else. (Demmers 20)

Social identity is the relationship between the people and the surroundings. It tells us about "the categorical characteristics - such as nationality, gender, religion, ethnicity that locate people in social space" (Demmers 20). But people have multiple identities. A person can be a teacher, a father, a political activist, a Hindu, a Madhesis at the same time. But the social identities of a person are different in different contexts. One identity becomes prominent in a specific context when others are less important which "only recede into the background" (Demmers 20). He opines that the "gender, ethnic, national identities are more permanent" ( Demmers 21).

9 Based on the opinions expressed by Hridesh Tripathee in the interview with Rajesh Mishra in Kantipur on December 4, 2016. 
There is an interface between social identity and the group conflict. Many conflicts in the world have occurred in the name of identities. According to Demmers;

It is not hard to see the salience of social identity in violent conflict. Very often social identities such as ethnicity, religion, clan or nation are seen as the primary fault line between groups in conflict. People seem to be willing and be able to kill and die in name of the groups. (22)

Culture is an important identity of people which includes ethnicity, language, religion, customs, norms and values that makes them different among each other. They tend to think as "we are what we are not" (Demmers 20). Culture shapes the way of living, habits, behaviors and performance of the people. Cultural norms and values are often "at the core of human development and informed coexistence and are founded and bonded on specific sets of principles that guide human behavior" (Latigo 85). Human psychology or the cognition, and the activities are shaped by the culture.

Communal identity, which is also known as socio-cultural identity, is very important to the people no matter where they are living. Many conflicts have been occurred when the communal identities are (not) recognized properly. According to Edward Azar;

Protracted social conflicts occur when communities are deprived of satisfaction of their basic needs on the basis of their communal identity. However, the deprivation is the result of a complex casual chain involving the role of the state and the pattern of the international linkages. (quoted in Demmers 79)

Cultural identity shapes the emotion of the people. If the emotion and the sentiment of the people in a certain locality is not properly understood and addressed they will be prone to violence. "Both emotional and rational factors are important for collective violence" (Demmers 89). Emotion reflects out of the feeling of ethnic or communal identity, whereas, rational feeling appears by calculating the benefits or the opportunities in the group.

The state should properly respect the identity of all the citizens living in the country. It should not be bias to any identity groups. It has to guarantee the "participation of all groups in the affairs of the state as well as equity in the sharing of its resources. Identity groups tend to demand self determination, or assert their rights to be treated equally with all citizens, precisely when a state is not fulfilling these objectives"(Bloomfield, Ghai and Reilly 36). Moreover, the state should act and behave like the parent to its children hearing and addressing the demands of all the citizens.

In his 'conflict model' Azar further presents these four steps to explain the sources of conflict, which are: "communal content, deprivation of human needs, the state, and international linkages" (79). If there are multiple communal identities, there remain 
more possibilities of violent conflict because one identity group tries to undermine or dominate the other and the latter revolts against. Each and every human being has certain 'human needs' and s(he) gets involved in the group having similar identity. The powerful identity group "may enjoy the satisfaction of needs (such as nutrition, warmth, security, self-actualization) in abundance, others do not" (80). In Nepal the state power was always controlled by Pahadi Chhetry-Bahun from the time of Prithvi Narayan Shah. "They made the rules and regulations in their own favour and discriminated and ruled the ethnic and Madhesis community" (Lawoti 44 - my translation). The Madhesh movement and other ethnic movements were the results of such grievances. Such grievances are generally expressed collectively, and if the state does not address it properly in time it results into protracted conflict. One of the important factors of the Madhesh conflict was the deafness or the ignorance of the Nepali state authorities who did not try to listen and address the issues raised by the Madhesis. Talking about how identities are formed Edward Azar explains that the "formation and acceptance of identity thus may also be understood as a basic development need, with collective identity manifest in terms of cultural values, images, customs, language, religion, and racial heritage" (quoted in Demmers 80) And while forming the identity, others' identities are ignored or simply rejected.

Even a trivial action can escalate the violent conflicts, for example the murder of Ramesh Mahato by Maoist cadres in Lahan on December 19, 2007 triggered the identity issue and caused the Madhesh movement in 2007. Azar further opines, "Communal actions and strategies involve the ways in which a specific event can trigger communal action and escalate into overt conflict. Initially, the trigger may, but need not be, a trivial incident" (quoted in Demmers 82). The murder of Ramesh Mahato in Lahan made all the Madhesis feel that it's an attack on their community. All felt pain in the death of Mahato. Such "communal actions and strategies are shaped by the responses of political authorities" (quoted in Demmers 82).

According to Edward Azar, "conflict is not determined exclusively from within, but also importantly from without: by the patterns of linkage within the international system" (quoted in Demmers 81). He means to say that there is an important role of international politics or international agencies with the similar interest and identity groups to create or to add the conflict of another country. During the research many of the respondents assured me that there was a direct and indirect connection from the people from the neighbouring provinces of India that has direct socio-cultural and border connection to the Madhesh. It is not a surprise because the conflict in a border area has direct impacts on both sides of the border. Moreover the Madhesis people are socio-culturally and economically linked with the people near the border. "Madhesis people from Nepal have familial and socio-cultural relationship with the people from 
UP, Bihar and Bangal which are across the border. It's not strange to get the support to the Madhesis from the people across the border"10. It's not a new phenomenon because there were direct supports from the people of India in all democratic movements that changed the political system in Nepal.

Some of the state administrators and Pahadi people had intense hatred towards the Madhesis. They tried to demean and humiliate the Madhesis people calling them 'Deshi', 'Bihari Bhaiya', 'Dhoti'. ${ }^{11}$ According to Ramawatar Yadav, people in Kathmandu felt as if Madhesh is not in Nepal, and Pahadi people only are Nepali. He shares an experience in this way:

An erstwhile colleague of mine was appointed Chairman of the Nepal Public Commission. One day during a conversation, he was a little too keen to learn about the exact location of my village-- lest I was an Indian. In answer to his query, I named a couple of neighboring villages--one of which he happened to have known about. No sooner had I named that certain village than the chairman interjected: "Yeah, but isn't it the same village where some Nepali families live?" (Yadav 152)

Yadav's friend's understanding was that the Pahadi people also were living in that village which is as if not in Nepal because almost all residence living there were Madhesis. It was the typical mentality and belief of all Pahadi people living in Kathmandu and the hilly regions of Nepal that they didn't recognize the Madhesis people as 'Nepali' no matter how long they have been living in the land of Terai; and so they did not hesitate to call Madhesis 'Bihari Bhaiya'. Some of the people from Newar communities in Kathmandu valley do not see them like men. "When they see the Madhesis, near their house, they report to each other: 'manu makhu, marsya kha' (not a man, just a Madhesis)" (Maharjan 9-my translation).

While answering the question asked by the researcher about the reasons of the Madhesh movement of 2015, one of the secondary school teachers from Mahottari district explained, "It is to prove that the Madhesh also is in Nepal, and the Madhesis are Nepali people. Leaders in Kathmandu wouldn't otherwise listen the problems of Madhesis, because they have a misconception that we Madhesis are not Nepali"12

Both the Madhesh movement of 2007, and 2015 had raised similar demands. But it

10 Opinions expressed by Nabal Kishor Chaudhari, an Indian economist and professor in the interview by Basanta Basnet in Kantipur on December 18, 2016.

11 By calling Madhesis people Deshi and Bihari Bhaiya the Pahadi people demean them as foreigners. Pahadis had a misconception that the Madhesis have come to Nepal from Bihar, India. Madhesis people wear Dhoti, their ethnic dress, but it is an insult of so-called national Pahadi people to them.

12 Based on the researcher's discussion with Suman Karna (name changed) from Jaleshwor, Dhanusa on November 24, 2016. 
seems the latter was for the fulfillment of the rights that were guaranteed by the Interim Constitution and other previous agreements between Madhesis and the government. According to JP Gupta, the president of Madhesis People's Right Forum (Republic) (MPRF (R) the Madhesh Movement of 2007 was held with the agendas like: "the recognition of the Madhesis, autonomous Madhesh state, representation of the Madhesis in the state, constitutional guarantee for the linguistic rights, and inclusiveness" (quoted in Sah 26- my translation). That movement, from his perspective was purely a political.

But Mr. Sharma, an inhabitant from Tikapur, Kailali, a district in the

far western Madhesh has different opinion. He reasons; "both Madhesh movements were the results of Maoist's design of separate ethnic states like Limbuwan, Tamsalin, Newa, Magarat, Bhojpura, Tharuhat, etc. This is influenced from ethnic movements throughout the country"13 It was a type of revolt from marginalized community against the state that always excluded them. The revolt became stronger after they realized that their expectations were not properly addressed by the new constitution.

\section{Conclusion}

In spite of having productive geographical structure with infinite possibilities, the Madhesh has been suffering from two types of problems. The first problems lies within Madhesh itself; and the second is the legacy of exclusionary nature of the state and Non-Madhesis rulers from Shah Dynasty to Rana and Panchayat. The second problem is relatively more explicit and brought into the political agendas through different movements. The Madhesh Movement 2015 occurred because of these both reasons.

It is found that the problems within Madhesh itself are more complex. The caste and class discrimination, corruption, poverty and illiteracy, lack of political consciousness, boarder crisis, and lack of visionary leadership to represent from real grassroots of Madhesh are some important problems that the Madhesh has been facing for long. The suppressed and dominated or exploited voices try to get freedom out of such condition, The Madhesh Movement II is the same expression from the Madhesh.

\section{References}

Bhattachan, Krishna B. "Ethnopolitics and ethnodevelopment: an emerging paradigm in Nepal - with a postscript." ed. Hangen, Susan and Lawoti, Mahendra. Nationalism and Ethnic Conflict in Nepal. London: Routledge, 2013. 35 - 57. Print.

Bloomfield, David, Ghai Yash and Reilly, Ben “Analysing Deep-Rooted Conflict.” ed. Harris, Peter and Reilly, Ben. Democracy and Deep-Rooted Conflict: Options for

13 Based on the answers given by the respondent Mr. Sharma from Tikapur, Kailali to the researcher, on November 5, 2016. 
Negotiators. Stockholm: International IDEA, 1998. 29-58. Print.

Chaudhari, Randhir, "Southern blues." The Kathmandu Post 30 Dec. 2016. Print.

Demmers, Jolle. Theories of Violent Conflict. New York: Routledge, 2012. Print.

Gunaratne, Arjun. "Introduction." ed. Gaige, Fredrich H. Regionalism and National Unity in Nepal. $2^{\text {nd }}$ ed. Lalitpur: Himal Books, 2009. Print.

Hachhethu, Krishna. "Chhetriya Rastrabad Ra Madhesis Dal.” ed. Maharjan Rajendra and Sah Tula Narayan. Madhesh Adhyayan. Year 2, Issue 3. Lalitpur: NEMAF, 2013. 27-42. Print.

Hangen, Susan and Lawoti, Mahendra. "nationalism and ethnic conflict in Nepal." ed. Hangen, Susan and Lawoti, Mahendra. Nationalism and Ethnic Conflict in Nepal. London: Routledge, 2013. 5 - 34. Print.

NEMAF. Harmony, Security and Governance in the Plains. Lalitpur: NEMAF, 1013. Print.

Jha, Dipendra. "Better luck next year." Kathmandu Post 1 Jan. 2017. Print.

Lal, C. K. "A dysfunctional state." Republica 11 Jan. 2016. Accessed on 11 July 2016, web: http://admin.myrepublica.com/opinion/story/34733/a-dysfunctional- state. httm\#sthash.7cWD2WtL.dpuf.

- - - . "Rotary of revolutions". Republica 16 January 2017. Print.

- - - . "Message from Madhesh". Republica 7 Nov. 2016. Print.

- - - - "Tarai Madhesh Ma Aantarik Upanibeshbad Ko Artha-rajniti.” ed..

Latigo, James Ojera. "Northern Uganda: tradition-based practices in the Acholi region." ed. Huyse Luc and Mark Salter. Traditional Justice and Reconciliation after Violent Conflict, Stockholm: International IDEA, 2008. 85-119. Print.

Lawoti, Mahendra. "Madhesh Andolan Kina Chadai Bhhayo?" ed. Maharjan, Rajendra and Shah, Tula Narayan. Madhesh Adhyayan. Year 2, Issue 3, Lalitpur: NEMAF, 2013. 43-73. Print.

Maharjan, Rajendra. "Manu Makhu, Marsya?” ed. Maharjan, Rajendra. Madhesh Adhyayan. Year 1, Issue 1. Lalitpur: NEMAF, 2013. 9-14. Print.

Mathema, Kalyan Bhakta. Madhesis Uprising. Kathmandu: Mandala Books, 2011. Print.

Mishra, Pramod, "Together We Stand.” The Kathmandu Post 18 August 2016. Print. Pradhan, Keshav. "India the big loser in divided Nepal." Times of India 2 October 2015. Accessed on 14 August 2016, web: http://timesofindia.indiatimes.com/ 
india/India-the-big-loser-in-divided- Nepal/articleshow/49190134.cms

Premarshi, Dhirendra and Sah, Tula Narayan, ed. Madhesh Manthan-4 Madhesh Bidroha ko Panch Barsa: Upalabdhi ra Chunauti. $2^{\text {nd }}$ ed. Lalitpur: NEMAF, 2013. Print.

Sah , Krishna Kumar. “A History of Exclusion.” Kathmandu Post 23 Aug. 2016. Print.

Sah, Tula Narayan, ed. Madhesh Manthan-8 Samajik Sadbhab: Bahuaayamic Bahas Lalitpur: NEMAF, 2013. Print.

Sharma, Saurav. “Terai Madheshma Bibhed Chha." Gorkhapatra 23 Dec. 2016. Print

Sijapati, Bandita. "In persuit of recognition: regionalism, Madhesi identity and Madhes Andolan." ed. Hangen, Susan and Lawoti, Mahendra. Nationalism and Ethnic Conflict in Nepal. London: Routledge, 2013. 145 - 172. Print.

Timilsina, Balaram. "Terai Madhesh Bare Bhram.” Gorkhapatra 26 Dec. 2016. Print.

Upadhya, Akhilesh, "Nepal, Between the Dragon and the Elephant." Now York Times 6 Nov. 2015. Accessed on 16 July 2016, web: http://query.nytimes.com/ search/ sitesearch/? action $=$ click \& content Collection \& region= TopBar $\underline{\&}$ WT.nav $=$ search Widget $\&$ module $=$ Search Submit $\&$ pgtype $=$ Topic \#l backoffindia

Yadav, Ramawtar Yadav. "On Being Madhesi." ed. Guneratne Arjun. The Tarai: History, Society, Environment. Kathmandu: Himal Books, 2011. 150-160. Print. 